\title{
ENTREVISTA
}

\section{JOGOS EM CENA}

\author{
Entrevistas concedidas a \\ Angela Paiva Dionisio* \\ Tatyana Mabel Nobre Barbosa**
}

"O jogo é mais antigo do que a cultura, pois mesmo em suas definições menos rigorosas o conceito de cultura sempre pressupõe a sociedade humana; mas, os animais não esperaram

que os homens lhes ensinassem a atividade lúdica. É-nos possível afirmar com segurança que a civilização humana não acrescentou característica essencial alguma à ideia geral de jogo.

Os animais brincam tal como os homens.

(...)

Se brincamos e jogamos, e temos consciência disso, é porque somos mais do que simples seres racionais, pois o jogo é irracional."

Nesta seção, registramos vozes de reconhecidos educadores no cenário nacional e internacional cuja trajetória acadêmica é dedicada ao ensino de qualidade. Em seus depoimentos, evidenciam-se o respeito à diversidade, a importância da inclusão e necessária formação integral dos alunos em um ambiente de construção coletiva, de valorização dos docentes e de todos que são peças chave na educação democrática e cidadã deste país chamado Brasil.

Qualquer que seja o ponto de vista adotado, o que emerge destas vozes são características do trabalho com o uso dos jogos naquilo que nos permite inscrevê-lo no âmbito do que se tem vindo a chamar a pedagogia dos multiletramentos (Multiliteracies Pedagogy), por meio da qual o New London Group aspirava a construir melhores aprendizagens para melhores futuros. Nas salas de aula aqui configuradas, implícita ou explicitamente, podemos encontrar os traços da "aprendizagem situada", ou seja, a construção de conhecimento em contextos de vida reais, de forma partilhada e colaborativa, em comunidades de aprendizagem; marcas de "aprendizagem explícita", pela qual os alunos adquirem metalinguagem e desenvolvem consciência e controle de conceitos, regras e procedimentos; evidências também de "enquadramento crítico" e de "prática transformada", ou seja, de produção de novos significados, resultantes do

\footnotetext{
* Professora visitante no PPGLE da UFCG; é professora titular aposentada da Universidade Federal de Pernambuco. Coordenou a área do PIBID Letras/Português UFPE, juntamente com Suzana Cortez (20142016). Atuou como professora e orientadora no PROFLetras UFPE (2013-2015). Possui graduação em Licenciatura Plena em Letras pela Universidade Federal de Campina Grande (1986), mestrado (1992) e doutorado em Linguísitica (1998) pela Universidade Federal de Pernambuco. E-mail: angela_dionisio@uol.com.br

** Professora Associada I da Universidade Federal do Rio Grande do Norte. Tem experiência na área de Educação, com ênfase em Educação e linguagem, atuando principalmente nos seguintes temas: autobiografias, relações de gênero, ensino de língua portuguesa, educação básica, políticas de leitura, políticas linguísticas. E-mail: tatyanamabel@uol.com.br

${ }^{1}$ HUIZINGA, Johan. Homo Ludens (Estudos). Editora Perspectiva S/A. Edição do Kindle, 2019.
} 
conhecimento construído de forma refletida, significados esses (re)interpretados à luz dos contextos e motivações histórico sociais em que ocorrem.

Em suma, as experiências com os jogos que aqui nos são trazidas dão conta de como esta ferramenta potencia processos pelos quais os alunos aprendem integrando o já conhecido e o novo.

\title{
GAMES ON THE SCENE ${ }^{2}$
}

\begin{abstract}
"Games are older than culture, since, even in the less rigorous definitions, the notion of culture always presupposes human society; however, animals did not wait for men to teach them playful activities.

It is possible for us to safely claim that human civilization has not added an essential characteristic to the initial conception of games.

Animals play just as men do.

If we play and enjoy ourselves, and we are aware of that, it is because we are more than simple rational beings, because games are irrational".
\end{abstract}

In this section, we register the voices of nationally and internationally renowned educators whose academic trajectories are dedicated to qualified teaching. In their testimonials, there are evidences of respect to diversity, the importance of inclusion and the necessary integral education of students in an environment for collective construction, valorization of teachers and all of those who are essential for the democratic, citizenship-oriented education in Brazil.

Regardless of the point of view, these voices give rise to the characteristics of the work with games in a way that allows us to inscribe them in the scope of what has been named the Multiliteracies Pedagogy, through which the New London Group aspired to construct better learnings for better futures. In the classrooms discussed here, either implicitly or explicitly, it is possible to find: traces of "situated practice", that is, the construction of knowledge in real life contexts in collaborative and shared ways, in communities of learning; marks of "over instruction", through which learners acquire metalanguage and develop awareness and control of concepts, rules and procedures; evidences of "critical framing" and "transformed practice", that is, the production of new meanings derived from knowledge that was built reflexively, new meanings that are (re)interpreted under the light of the contexts and of the social-historical motivations in which they take place.

In short, the experiences with games described here account for how these tools optimize processes through which students learn by integrating the known and the unknown.

\footnotetext{
${ }^{2}$ Tradução de Larissa de P. Cavalcanti (UFRPE-UAST; email para contato: laracvanti@gmail.com), exceto o depoimento de Maria de Lourdes Trindade Dionísio, que foi feito pela própria autora. 


\section{Com a palavra...}

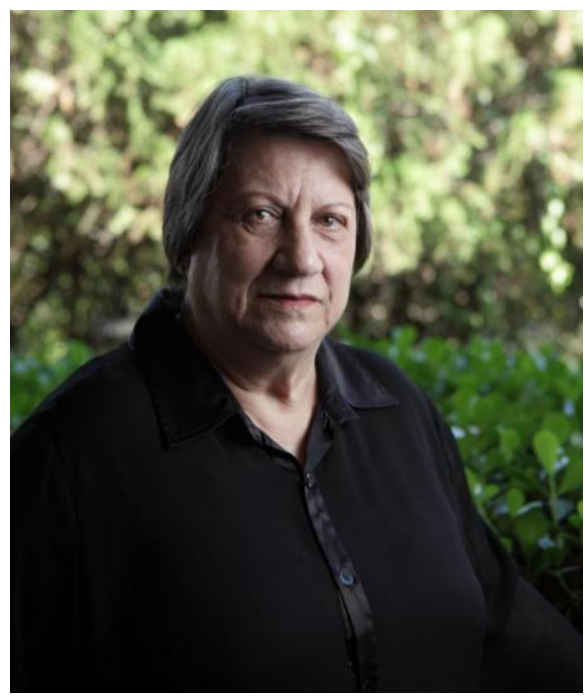

\section{Magda Soares (UFMG)}

Estou plenamente de acordo com o princípio de que os jogos, sobretudo na educação infantil e nas séries iniciais do ensino fundamental, têm, como principal objetivo, o desenvolvimento de habilidades cognitivas, sociais e eventualmente tecnológicas (digo "eventualmente" porque, neste caso, são necessários recursos raramente disponíveis em escolas públicas, e respondo pensando nelas e nas crianças das camadas populares que as frequentam). Seu caráter intrinsecamente lúdico motiva as crianças, portanto, facilita e reforça o desenvolvimento dessas habilidades.

Com isso quero dizer que o uso de jogos como ferramentas educativas se justifica sobretudo por sua ação sobre o desenvolvimento das crianças, e é esse o critério para escolhê-los e usá-los. Claro que há momentos em que o jogo pode ter por objetivo dar oportunidades para que as crianças se divirtam, desenvolvam-se do ponto de vista também físico, motor; neste caso, está também subjacente o desenvolvimento cognitivo e principalmente social, embora não como critério para escolha do jogo, que pode ser feita pelas próprias crianças.
Uma observação que gostaria de fazer é que, embora o mais comum e mais fácil seja usar jogos comerciais ou oferecidos na internet por instituições educativas, considero de grande valia também os jogos que são criados pela professora com a colaboração das crianças, porque a construção do jogo também desenvolve, e muito, habilidades cognitivas e sociais, na medida em que a professora vai definindo, junto com as crianças, as estratégias para a criação de um jogo. Minha experiência na orientação que venho fazendo, há vários anos, das professoras do ciclo de alfabetização e do letramento de uma rede municipal de Minas Gerais (Lagoa Santa) confirma o valor relevante para o desenvolvimento cognitivo e social das crianças de jogos construídos em sala de aula, em colaboração de professora e crianças, buscando e executando soluções para que o jogo atinja seus objetivos.

\section{English version}

I fully agree with the principle that games, particularly for kindergarten and primary grades, have as their main objective the development of cognitive, social and, on occasion, technological skills (I say "on occasion" because there are resources that are seldom available or public schools, and my answer takes into account these schools and the children who attend there). The intrinsic ludic nature of games motivates children, and facilitate and reinforce the development of those skills.

I mean to argue that using games as educational tools is justified particularly due to its action for the development of children, which is the criterion to select and use them. Naturally, there are moments when games aim at creating opportunities for children to have fun, to develop from a physical and motor perspective; in these cases, the cognitive and, mostly, the social development are subjacent, but not as criterion to choose 
the game, which can be made by the own children.

One observation I would like to make is that, although commercial games or games available on the internet by educational institutions are more popular and easier to use, I also deem valuable games created by the teachers in collaboration with children, because the making of the game also develops, and a lot, cognitive and social skills, as the teacher defines with the children strategies to create games. My years of experience advising teachers in the alphabetization and early literacy cycles in municipal schools in Minas Gerais (Lagoa Santa) confirm the significance, for the cognitive and social development of the children, of games built in the classroom withcollaboration of teachers and children, searching for and working out solutions for the game to fulfill its purposes.

\section{Com a palavra...}

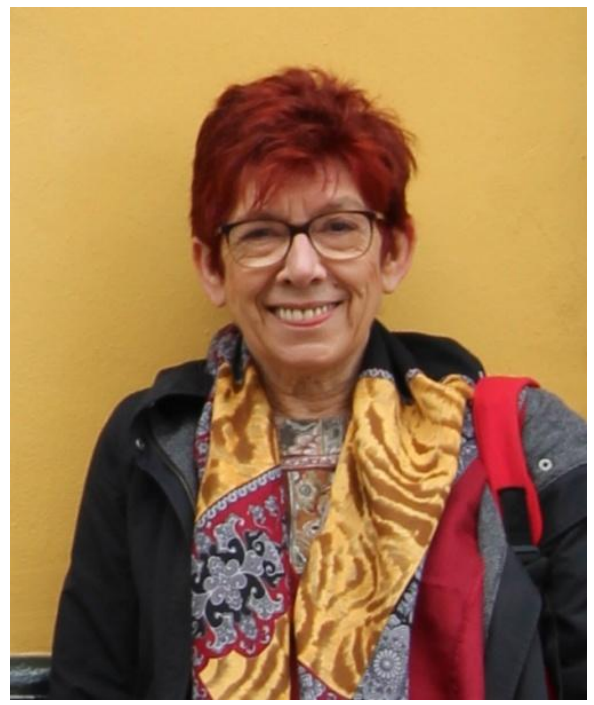

\section{Maria de Lourdes Dionísio} (UMinho, Portugal)

Usar jogos para ensinar e aprender tem uma longa história nas salas de aula das sociedades ocidentais. Na sua base, encontramos a defesa de que "a aprendizagem pode e deve ser muito divertida" (QUINN,2005, p. 11) ${ }^{3}$ e que, por isso mesmo, usar jogos para ensinar e aprender não pode ser entendido como uma perda frívola de tempo, mas sim um "prazer que devemos assumir sem culpa nem preconceito" (QUINN, 2005, p. 15). A motivação e a possibilidade que o jogo tem de trazer relaxamento e diversão, em ambientes descontraídos de competição amigável têm sido, ao longo já de algumas décadas de investigação e prática, o argumento mais forte para trazer o jogo e/ou atividades tipo jogo para dentro da sala de aula.

No caso da aprendizagem da/s língua/s, os contributos dos jogos são igualmente vistos neste quadro de motivar o desmotivado e de reduzir a tensão e ansiedade dos menos confiantes e fluentes, dada a ênfase na mensagem e não na forma. Mas também e, sobretudo, no criar de contextos significativos para usar a linguagem que propicia, estimulando a prática do falar, escrever, ouvir e ler. Não será exagerado afirmar que é já consensual que o jogo ajuda a desenvolver a compreensão e a melhorar as competências de comunicar e interagir. Para além destas competências linguísticas, sabe-se que o jogo encoraja a aprendizagem cooperativa e o trabalho em equipa, bem como o desenvolvimento do que se tem chamado as competências do século XXI, nomeadamente, as de resolução de problemas, a criatividade e o pensamento crítico.

Contudo, o recurso aos jogos, sejam eles os tradicionais ou cada vez mais os digitais, assenta hoje em pressupostos que estão para lá da simples ideia de que os jogos são pausas bem vindas nas rotinas usuais da aula. A sua defesa como ferramentas de aprendizagem decorre do reconhecimento de que os jogos operam e incentivam bons princípios de aprendizagem, por exemplo, a participação ativa e crítica na

${ }^{3}$ QUINN, Clark. Engaging Learning. San Francisco: Pfeiffer, 2005. 
aprendizagem, a capacidade de manipular múltiplos sistemas semióticos para construir sentido, o engajamento prolongado sem desmobilização, a experimentação de vários caminhos para progredir, testando possibilidades e redefinindo percursos, fazendo escolhas. As competências dos alunos não são desenvolvidas isoladamente ou fora do contexto e, nesta aprendizagem situada, geram-se inúmeras oportunidades para praticar e ajudar a transferir o que se aprendeu para resolver novos problemas. Por meio de jogos, os sentidos e o conhecimento são construídos não exclusivamente por recurso ao modo verbal, mas integrando imagem, símbolos, sons, etc., ou seja, participando em situações verdadeiramente multimodais. Neles, os textos não são entendidos apenas em termos dos significados das palavras que os compõem e das relações que essas palavras estabelecem entre si; ao contrário, os significados são situados e, nesse sentido, são construídos em termos de experiências vividas corporeamente.

Reconhece-se, ainda, que nas aprendizagens realizadas com os jogos, os alunos podem desenvolver modelos culturais, pensando consciente e reflexivamente sobre algumas das suas atitudes face ao mundo, e nelas sobre a importância da aprendizagem e de como se aprende.

Todos estes princípios, que podem ser igualmente adotados quer como quadro analítico quer como guião orientador de práticas de sala de aula são, segundo James Paul Gee (2004, 2007, $2013)^{4}$ melhores do que aqueles das escolas orientadas exclusivamente por

\footnotetext{
4 GEE, James Paul. Situated language and learning: A critique of traditional schooling. London: Routledge, 2004; Situated language and learning: A critique of traditional schooling. London: Routledge, 2007; Good video games and good learning: Collected essays on video games, learning and literacy (2nd ed.). New York: Peter Lang, 2013.
}

princípios de avaliação que apenas levam ao insucesso e ao abandono.

A sua adopção na estruturação de oficinas de literacia desenvolvidas com crianças de contextos desfavorecidos do Vale do Minho, em Portugal (DIONÍSIO, OLIVEIRA, MARTINS, CUNHA, 2007) $)^{5}$, e cujos principais objetivos foram i) envolver os jovens em práticas culturais diversificadas e socialmente representativas, particularmente aquelas em que os 'textos' desempenham um papel relevante; ii) por meio da socialização na multiplicidade de Discursos e nas variadas configurações do conhecimento, proporcionar a aquisição de modelos culturais que possibilitassem a compreensão dos sentidos produzidos particularmente na escola, criou condições para que os jovens se tornassem "insiders" (GEE, 2004) de domínios de saber específicos e, alternando papéis de alunos e professores, fossem produtores ativos de conhecimento, não apenas consumidores. Nestas oficinas, onde os jogos também marcaram presença, ficou demonstrado que as aprendizagens significativas são as que acontecem em cenários autênticos, onde os sujeitos desempenham múltiplos papéis leitores e sociais.

\section{English version}

To use games to teach and learn has a long history in the classrooms of Western societies. At its base, we find the defense that "learning can and should be a lot of fun" (QUINN, 2005, p. 11) and that, therefore, using games to teach and learn cannot be understood as a frivolous loss of time, but rather a "pleasure that we must assume without guilt or prejudice"

${ }^{5}$ DIONÍSIO, M ${ }^{\mathrm{a}}$ de Lourdes, OLIVEIRA, Mónica, MARTINS, Lurdes, e CUNHA, Lídia, (Con)viver com as Letras ou do que foram e como foram as oficinas das Novas Experiências com a Literacia no Vale do Minho. In GONÇALVES, Albertino, VIANA, Fernanda Leopoldina, DIONÍSIO, Maria de Lourdes, Dar Vida às Letras: Promoção do Livro e da Leitura. Valença: Comunidade Intermunicipal do Vale do Minho, 2007, pp. 47-58. 
(QUINN, 2005, p. 15). The motivation and the possibility that the game has to bring relaxation and fun, in relaxed environments of friendly competition have been, for some decades of research and practice, the strongest argument to bring the game and/or game-like activities to inside the classroom.

In the case of learning language/s, the contributions of the games are also seen in this context of motivating the unmotivated and reducing the tension and anxiety of the less confident and fluent, given the emphasis on the message and not on the form. But also and, above all, in the creation of meaningful contexts to use the language it provides, stimulating the practice of speaking, writing, listening and reading. It will not be exaggerated to say that it is consensual that the game helps to develop understanding and improve the skills of communicating and interacting. In addition to these language skills, it is known that the game encourages cooperative learning and team work, as well as the development of what has been called 21 st century skills, namely problem solving, creativity and thinking critical.

However, the use of games, whether traditional or increasingly digital, is based today on assumptions that go beyond the simple idea that games are welcome breaks in the usual routines of the class. Its defense as learning tools stems from the recognition that games operate and encourage good learning principles, for example, active and critical participation in learning, the ability to manipulate multiple semiotic systems to make sense, prolonged engagement without demobilization, experimenting with various paths to progress, testing possibilities and redefining paths, making choices. Students' skills are not developed in isolation or out of context, and in this situated learning, there are numerous opportunities to practice and help transfer what has been learned to solve new problems. Through games, the senses and knowledge are constructed not exclusively by using the verbal mode, but by integrating image, symbols, sounds, etc., that is, participating in truly multimodal situations. In them, texts are not understood only in terms of the meanings of the words that compose them and of the relationships that these words establish with each other; on the contrary, meanings are situated and, in this sense, they are constructed in terms of embodied experiences. It is also recognized that in the learning carried out with games, students can develop cultural models, thinking consciously and reflexively about some of their attitudes towards the world, and in them about the importance of learning and how to learn.

All of these principles, which can be equally adopted both as an analytical framework and as a guide for classroom practices, are, according to James Paul Gee $(2004,2007,2013)$ better than those of schools guided exclusively by assessment principles that only lead to failure and drop out.

Its adoption in the structuring of literacy workshops developed with children from disadvantaged contexts in the Vale do Minho, Portugal (DIONÍSIO, OLIVEIRA, MARTINS, CUNHA, 2007), and whose main objectives were i) to involve young people in diverse and socially representative cultural practices, particularly those in which 'texts' play a relevant role; ii) through socialization in the multiplicity of Discourses and in the varied configurations of knowledge, providing the acquisition of cultural models that enabled the understanding of the meanings produced particularly at school, created conditions for young people to become "insiders" (GEE, 2004) of knowledge domains, so that alternating roles of students and teachers, they were active producers of knowledge, not just consumers. In these workshops, where games were also present, it was demonstrated that significant learning is that which takes place in authentic settings, where the subjects play multiple reader and social roles. 


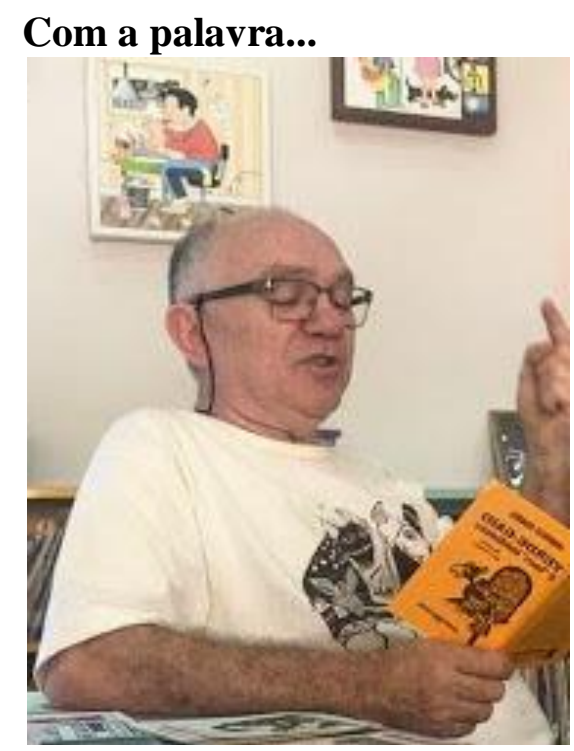

José Hélder Pinheiro (UFCG)

Não há dúvidas de que os jogos acompanharam os homens ao longo da história. E, claro, não apenas jogos no sentido competitivo que predomina hoje. Bem antes do modelo de escola moderna, eles permeavam as mais diversas atividades humanas. $\mathrm{E}$ a dimensão lúdica dos jogos sempre foi e continua sendo fundamental. É através desta dimensão que se pode desenvolver a dimensão cognitiva, física, psicológica, afetiva e muitas outras. Portanto, ela não é uma coisa anterior, uma escada, um anteparo para, pragmaticamente, chegar a algo maior - por exemplo, a cognição.

Pensemos aqui a dimensão do jogo no âmbito da linguagem e, mais especificamente, do jogo com as palavras. Joga-se com as palavras para gerar ambiguidades, efeitos sonoros e semânticos os mais diversos. Uma adivinha, por exemplo, pode estimular a imaginação, a reflexão, conhecimentos geográficos, históricos, do cotidiano, bem como a percepção de aproximações semânticas. E o que são as advinhas, senão, poemas orais, em que som e sentido quase sempre se aliam? A poesia é a arte que mais lança mão do ludismo com as palavras. Lembra Huizinga, "Toda poesia tem origem no jogo: o jogo sagrado do culto, o jogo festivo da corte amorosa, o jogo marcial da competição, o jogo combativo da emulação e da troca e da invectiva, o jogo ligeiro do humor e da prontidão." A seguir, pergunta: "Até que ponto se mantém esta qualidade lúdica da poesia, à medida que a civilização se vai tornando mais complexa?" " A pergunta é crucial, uma vez que, sobretudo a escola pensar em formar, cada vez mais a dimensão cognitiva dos educandos. Até mesmo a dimensão lúdica é, muitas vezes, valorada quando favorecer a cognição. Huizinga, filósofo que nos legou a mais completa e complexa reflexão sobre o jogo em sua obra Homo ludens, afirma que a "ordenação rítmica ou simétrica da linguagem, a acentuação eficaz pela rima ou pela assonância, o disfarce deliberado do sentido, a construção sutil e artificial das frases, tudo isto poderia consistir-se em outras tantas manifestações do espírito lúdico."7

Se nos voltássemos com um pouco de atenção para nossa própria infância, talvez pudéssemos compreender melhor a importância da dimensão lúdica que permeava tudo que fazíamos, ouvíamos, sonhávamos. Quando criança, lembro-me de meu pai propor que repetíssemos a frase: "Paca, tatu, cotia, não." A gente repetia a frase inteira... Aí ele fazia uma pausa depois de cotia, e vinha o estalo: era para dizer só "paca tatu". Mas eu me demorava para entender a brincadeira com as palavras, com especial atenção aqui para a pausa para poder compreender o que se propunha. Outra brincadeira de que me lembro era a de novamente repetir os versos: "Quero que você me diga/ Cinco veisencarriado/ sem errar, sem tomar fôlego/ Vaca preta boi pintado" (transcrevi em forma de quadra, percepção que tive muito tempo depois. Sonoridade e o ritmo são importantes na proposição).

${ }^{6}$ Huizinga, J. Homo Ludens: o jogo como elemento da cultura. São Paulo: Perspectiva, 1980, p.143-144.

${ }^{7}$ Huizinga, J. Homo Ludens: o jogo como elemento da cultura. São Paulo: Perspectiva, 1980, p. 147 . 
Pois bem, eu demorava a perceber o jogo que estava posto na construção. Aí vinha o clique: e eu repetia o último verso cinco vezes e acertava a proposta. Por certo a dimensão cognitiva se enlaça ao jogo lúdico com as palavras. $\mathrm{O}$ risco para mim é quando um se sobrepõe ao outro, como quase sempre fazem os exercícios com poemas em livros didáticos.

Lembro-me também dos inúmeros trava-língua - que não tinham esse nome para nós -, como por exemplo: "Em cima daquela serra tem uma arara loira. Falará arara loira? Arara loira falará?" Ora, normalmente estávamos em grupo e a brincadeira despertava risadas e mais risadas à medida que íamos tentando e nos atrapalhando com os sons. Adolescente, participando de um grupo de teatro, falávamos inúmeros trava-línguas, agora com uma função mais pragmática - treinar a dicção.

$\mathrm{Na}$ literatura de cordel, a presença do jogo com palavras é uma constante (também nas cantorias, nas disputas de emboladores de coco, nalgumas folias de reis e demais manifestações da cultura popular). Poemas sobre jogo e poemas ou fragmentos de poemas em que o jogo com as palavras, os trocadilhos abundam são constantes. Lembro os folhetos sobre "jogo do bicho", "futebol dos animais" e dos trava-línguas. O mais famoso travalíngua está na "Peleja do Cego Aderaldo com Zé Pretinho", em que aparece a hoje conhecida brincadeira: "Quem a paca cara compra/ paca cara pagará" e suas variações: "Pagará a paca cara/ Que a paca cara compra", etc. Imagine-se um desafio de violeiros, quando o adversário se atrapalha com os "P" e "C"... E no folheto é o que acontece com Zé Pretim que "trava a língua" e acaba perdendo o desafio.

E aqui trago uma inquietação minha - de certo modo, já apontada. A escola quer transformar tudo competência e habilidade. E para mim, a dimensão lúdica vai perdendo seu encantamento e o tiro sai pela culatra. É o que acontece com a poesia infantil, sobretudo nos livros didáticos. O encantamento melódico de "A bela bola rola/ a bela bola de Raul", do poema "Jogo de Bola", de Cecília Meireles, se transforma procedimento para diferenciar "P" de "B" e outras coisinhas. É como se o lúdico só valesse como ponto de partida para apreender um conceito, favorecer a assimilação de um saber.

Para mim, esses procedimentos, sobretudo na educação infantil e no fundamental 1 não contribuem para formação de uma sensibilidade, um ouvido atento à música das palavras, que tanto pode nos acalentar pela vida afora. E é com Huizinha que finalizo esse rápido depoimento, quando afirma que a poesia "está para além da seriedade, naquele plano mais primitivo e originário a que pertencem a criança, o animal, o selvagem e o visionário, na região do sonho, do encantamento, do êxtase e do riso. Para compreender a poesia precisamos ser capazes de envergar a alma da criança como se fosse uma capa mágica, a admitir a superioridade da sabedoria infantil sobre a do adulto."

\section{English Version}

There are no doubts that games have followed men throughout history, and, of course, not only in the prevailing competitive sense of today. Much before the modern school, games were part of several human activities. The ludic dimension of games has been and still is pivotal. It is through that dimension that the cognitive, physical, psychological, affective dimensions and many others can develop. Therefore, it is not a prior, a step or a springboard to, pragmatically, reach something bigger - for instance, cognition.

${ }^{8}$ Huizinga, J. Homo Ludens: o jogo como elemento da cultura. São Paulo: Perspectiva, 1980, p.133. 
Let us think, here, the issue of games in regard to language and, more specifically, games with words. Words are played to promote ambiguity, and various sound and semantic effects. A riddle, for example, can stimulate the imagination, the reflection, or the geographic, historic knowledge of daily life, as well as the perception of semantic approximations. And what are riddles if not oral poems in which sound and sense are usually allied? Poetry is the art the makes the most of word play. As Huizinga reminds us: "Every poetry is rooted in games: the sacred game of cult, the festive game of amorous courtship, the martial game of competition, the combative game of emulation, trade and invective, the quick game of humor and improvise" $"$. Next, he asks: "to which point the ludic quality of poetry is preserved as civilization becomes more complex?"10 The question is fundamental, because, mostly, schools focus on educating, more and more, the learner's cognitive dimension. Even the ludic dimension is often appreciated when it favors cognition. Huizinga, a philosopher that left us a complete and complex reflection on games in his Homo ludens, claims that "the rhythm or the symmetric order of language, the efficient accent through rhymes or assonance, the subtle and artificial construction of sentences, all of it could be constituted in many other manifestations of the ludic spirit." $"$.

\footnotetext{
9، Toda poesia tem origem no jogo: o jogo sagrado do culto, o jogo festivo da corte amorosa, o jogo marcial da competição, o jogo combativo da emulação e da troca e da invectiva, o jogo ligeiro do humor e da prontidão." (Huizinga, J. Homo Ludens: o jogo como elemento da cultura. São Paulo: Perspectiva, 1980, p.143-144).

10 “Até que ponde se mantém esta qualidade lúdica da poesia, à medida que a civilização se vai tornando mais complexa?" (Huizinga, J. Homo Ludens: o jogo como elemento da cultura. São Paulo: Perspectiva, 1980, p.133).

11 “ordenação rítmica ou simétrica da linguagem, a acentuação eficaz pela rima ou pela assonância, o disfarce deliberado do sentido, a construção sutil e artificial das frases, tudo isto poderia consistir-se
}

If we focused a bit more in our own childhood, perhaps, we could understand more the relevance of the ludic dimension that was present everything we did, we heard, we dreamt. As a child, I remember my father proposing the repetition of the following: "Paca, tatu, cotia, não". We would repeat the whole sentence... then he would pause after "cotia", and then we realized: we had to say "paca, tatu". But it took me a while to understand this game with words, with particular attention to the pause to understand what was proposed. Another game I remember was repeating the lines: Quero que você me diga/ Cinco veisencarriado/ sem errar, sem tomar fôlego/ Vaca preta boi pintado" (I transcribed into quartets, a perception that came to me much later. Sound and rhythm are important in the proposition). Well, it took me a while to realize the game posed in the construction. Then it occurred to me: if I repeated the last line five times, I would get the idea. Surely the cognitive dimension is interlaced with the ludic word play. The risk, in my opinion, is their superposition, which is almost always done by textbook activities with poems.

I remember the several tonguetwisters - that we did not name that way , such as "Em cima daquela serra tem uma arara loira. Falará arara loira? Arara loira falará?". Well, normally, we were in groups and the game made us laugh and laugh as we tried to repeat and mixed upthe sounds. As teenagers in a theatrical group, we would say numerous tonguetwisters but for a pragmatic reason - to exercise our diction.

In the cordel literature, the presence of word games is predominant (also in cantorias, in disputas de emboladores de coco, and some folias de reis as well as in other manifestations of

em outras tantas manifestações do espírito lúdico." (Huizinga, J. Homo Ludens: o jogo como elemento da cultura. São Paulo: Perspectiva, 1980, p.147). 
popular culture). Poems about games and poems or fragments of poems in which word play and puns abound are constant. I remember the flyers on "jogo do bicho", "animal football" and tongue-twisters. The most famous tongue-twister is in the "Dispute of the Blind Aderaldo against Zé Pretinho", paca cara compra/ paca cara pagará" and variations: "Pagará a paca cara/ Que a paca cara compra", etc. Imagine a dispute of violeiros, when the adversary mixes "P" and "C"... That is what happens to Zé Pretim twists his tongues and loses the challenge.

I bring, here, a concern of mine that has been pointed out in a way. The school wants to transform competences and skills. To me, this makes the ludic dimension lose its charm, and the plan backfires. That is what happens to children`s poetry, specially in textbooks. The melodic enchantment of "A bela bola rola/ a bela bola de Raul", from the poem "Jogo de Bola" by Cecília Meireles, transforms into a procedure to distinguish "P" from "B" and similar. It seems that the ludic is a starting point to learn a concept, to favor assimilation of knowledge.

These procedures, specially in kindergarten and primary school, to me, do not contribute to educate sensitivity or an ear that is keen to the music of words, which can lull us throughout life. I conclude this brief testimonial with Huizinha's claim that poetry "is beyond seriousness, in that most primitive and original to which the children, the animal, the savage and the visionary, in the realm of dream, of enchantment, of ecstasy and of laughter. To understand poetry, we need to bend the child's soul as a magic cape, to admit the superiority of children's over the adult's wisdom." (p. 133) ${ }^{13}$.

\footnotetext{
${ }^{12}$ No original: "Peleja do Cego Aderaldo com Zé Pretinho".

13 No original: "está para além da seriedade, naquele plano mais primitivo e originário a que pertencem a criança, o animal, o selvagem e o
}

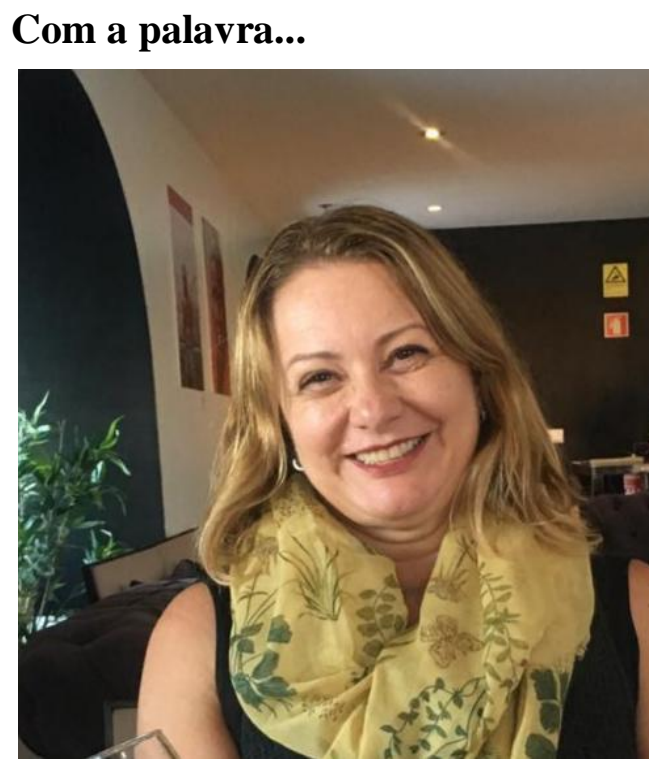

\section{Regina Lúcia Peret Dell’ Isola (UFMG)}

Os jogos têm sido uma alternativa importante na dinâmica das aulas de língua portuguesa. Mais do que ferramentas educativas voltadas para $\mathrm{o}$ aspecto lúdico em sala, inegavelmente, os jogos contribuem para o aprendizado, o desenvolvimento intelectual e o convívio social por permitir embates em que a civilidade e a ética devam prevalecer.

Em minha experiência em aulas de Português para alunos estrangeiros adultos, gostaria de ter recorrido mais com jogos. As aulas sempre foram divertidas quando os alunos eram desafiados a competir (e se controlar emocionalmente) ou a colaborar uns com os outros (em prol de um objetivo comum). Geralmente, os alunos sentiam-se motivados, quando participavam dos jogos propostos. As aulas eram alegres, havia participação, respeito às diferenças, atitudes de empatia, de solidariedade, e, para alcançar o objetivo do curso: havia comunicação.

visionário, na região do sonho, do encantamento, do êxtase e do riso. Para compreender a poesia precisamos ser capazes de envergar a alma da criança como se fosse uma capa mágica, a admitir a superioridade da sabedoria infantil sobre a do adulto." (Huizinga, J. Homo Ludens: o jogo como elemento da cultura. São Paulo: Perspectiva, 1980, p.133). 
Todos os alunos interagiam, comunicavam-se; até os mais tímidos se expressavam em português, que era a língua comum nas turmas sempre heterogêneas.

Os jogos cooperativos aplicados ao ensino pressupõem a troca de informações e convivência, porém é importante que o professor tenha a sensibilidade de conduzir o trabalho; de saber o momento de interromper a atividade - em caso da ocorrência de conflitos indesejáveis - e de controlar os ânimos nas disputas. Talvez, o mais importante seja a retomada do que foi trabalhado na atividade. Para que o jogo faça sentido, cabe ao professor, ao final da atividade, evidenciar o conteúdo que foi explorado por meio de cada jogo.

Embora as tecnologias digitais possam contribuir favoravelmente com os jogos em aula, o acesso a elas, bem como o acesso a materiais que sejam um pouco mais dispendiosos (como fotocópias), ainda é um desafio. Nas turmas de português para refugiados, por exemplo, é praticamente impossível contar com material impresso. Nesse contexto, os jogos têm se mostrado produtivos, sobretudo quando as famílias aprendem juntas o idioma. As aulas tornam-se divertidas e não são dispendiosas, o que é uma necessidade quando se dispõe de poucos recursos.

Para finalizar, gostaria de reforçar a importância da preparação prévia. Tanto no plano de aula, quanto na explicação das regras do jogo para os alunos, a preparação prévia tende a garantir que a atividade aconteça de uma forma mais prazerosa. $\mathrm{O}$ improviso nem sempre é bem-vindo, mas a criatividade tem seu lugar! O jogo deve ser levado tão a sério quanto uma aula expositiva.

\section{English Version}

Games have been an important alternative in Portuguese language lessons. More than educational tools that turn to the ludic aspect in class, undeniably, games contribute with learning, intellectual development and social experience by allowing confrontations in which civility and ethics must prevail.

In my experience as a Portuguese teacher for foreign adult learners, I wish I had used more games. Classes were always fun when learners were challenged to compete (and exercise emotional control) or to collaborate (toward a common goal). Generally, learners felt motivated when playing games: the classes were joyful, participative, respectful of differences, with attitudes of empathy, solidarity and, to reach the aim of the course, communicative. All learners interacted, they engaged in communication; even the shiest ones expressed themselves in Portuguese, which was the common language in classes that were usually heterogeneous.

Cooperative games applied to learning rely on the exchange of information and sociability, however, it is important for the teacher to be sensitive in the conduction of things; to know when to interrupt the activity in case of undesirable conflicts and to control the mood during disputes. Perhaps, the most important is to resume what the activity exercised. In order for the game to make sense, at the end of the activity, the teacher has to point the content exercised during the game.

Although digital technologies can positively contribute with using games in the classroom, their access as well as the access to materials that are more expensive (such as copies) are still a challenge. In Portuguese classes for refugees, for example, it is nearly to impossible to rely on print materials. Games, in that context, have shown to be productive, especially if families learn the language together. Classes become fun and are inexpensive, which is necessary when resources are limited.

Finally, I would like to reinforce the importance of preparation. In terms of both lesson plan and explaining the rules 
of the game for learners, preparation tends to ensure the activity is more pleasant. Improvisation is not always welcome, but creativity has its place! Games are to be taken as seriously as an explanatory lesson.

\section{Com a palavra...}

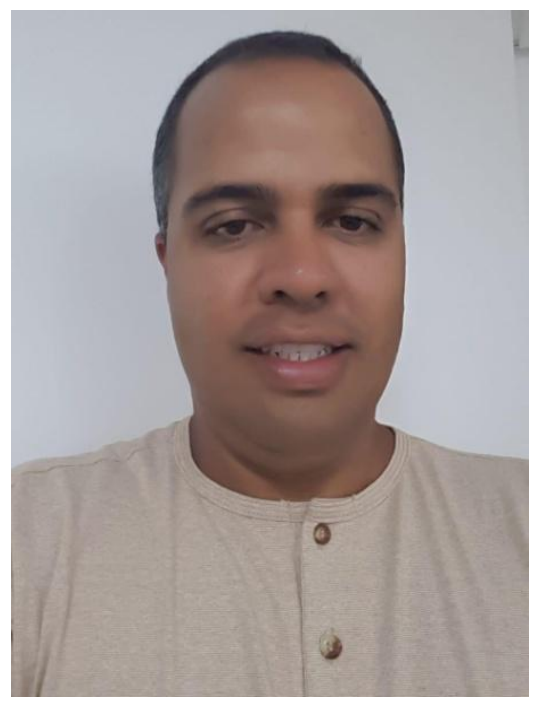

\section{Wagner Rodrigues Silva (UFT)}

Para responder o questionamento apresentado, assumo como ponto de partida uma experiência prática por mim desenvolvida na formação inicial de professoras de Língua Portuguesa para a primeira fase ou os primeiros anos do Ensino Fundamental. Minha ênfase no ensino superior não invalida a apreensão dessa experiência pelos leitores em função da problematização de práticas pedagógicas em outros contextos, a exemplo das salas de aula da Escola Básica. Quando direciono energias para inovar minha prática docente, não perco de vista as escolas brasileiras, onde a maioria das egressas da licenciatura atua. Os desafios laborais fazem os profissionais buscarem respostas para avançar em seus ofícios, mesmo que, equivocadamente, sejam apreendidos por alguns como justificativas para a inércia irresponsável. Recorrer a jogos como materiais ou recursos pedagógicos significa responder ativamente a desafios constitutivos do magistério.
Frequentemente, tenho sido confrontado com a precária formação linguística de ingressantes na Licenciatura em Pedagogia. São recorrentes as dificuldades dessas acadêmicas em práticas de leitura, de escrita e, principalmente, de análise linguística. $\mathrm{O}$ desafio se agrava diante do risco de manutenção das fragilidades elencadas, 0 que é provocado por um currículo asfixiante, parecendo ignorar que as denominadas educadoras polivalentes também são professoras de língua materna. A análise linguística tem ocupado uma posição central no meu trabalho como formador, pois a habilidade de reflexão sobre o funcionamento da gramática se faz necessária para o proveitoso trânsito das acadêmicas pela universidade e das professoras pela escola. $\mathrm{O}$ conhecimento gramatical pode auxiliar nas práticas de leitura e de escrita na universidade, o que se torna evidente, por exemplo, quando são encaminhadas reescritas de textos de gêneros acadêmicos. Por que a construção gramatical está inadequada? Quais são as motivações possíveis para o registro equivocado? Quais são as alternativas gramaticais para um registro mais apropriado? Questionamentos como esses precisam ser realizados e respondidos com alguma autonomia pelas acadêmicas. Esses mesmos conhecimentos gramaticais, com adicionais de saberes pedagógicos, são necessários na escola, evitando a reprodução da conhecida prática da tradição escolar, que se mostra pouco produtiva, especialmente para crianças de estratos sociais menos favorecidos.

Realço aqui o improdutivo ciclo, pois são essas conhecidas práticas responsáveis por inúmeros desafios trazidos pelas ingressantes à licenciatura focalizada. Para tanto, algum conhecimento gramatical explícito numa perspectiva funcionalista se faz necessário e, pela existência restrita de alguns resquícios de saberes da teoria gramatical prescritiva escolar, novos saberes 
precisam ser construídos, junto às professoras em formação, em reposta a situações práticas emergentes. A produção de jogos pedagógicos tem se mostrado um caminho promissor no contexto adverso descrito, incluindo a reduzida carga horária semestral reservada ao trabalho de metodologias para o ensino de língua.

Os jogos são produzidos com recursos diversos, desde materiais de papelaria, comuns em contextos escolares frequentados pelas acadêmicas, até materiais recicláveis, a exemplo de caixas de leite, garrafas plásticas e tampinhas de refrigerantes. Ao produzir os jogos, as futuras professoras se apropriam de saberes linguísticos de forma mais sustentável. É impossível adaptar ou, até mesmo, criar jogos para se trabalhar possibilidades de construções linguísticas, no nível da palavra ou da oração, por exemplo, sem algum conhecimento gramatical explícito. Por um lado, quase sempre, o aprendizado da reflexão metalinguística sobre dinâmicas da gramática do português tem sido árduo para as acadêmicas, o que não elimina a faceta lúdica presente na produção e uso dos jogos na própria disciplina; por outro lado, o alcance de uma maior conscientização sobre o funcionamento linguístico, garantindo alguma autonomia no trabalho com e sobre a língua materna, revela a sustentabilidade do trabalho desenvolvido, demandando também constante aprimoramento. Além do fortalecimento do que tenho denominado de letramento linguístico das futuras professoras, a produção e inserção de jogos dentro de um planejamento pedagógico têm gerado alguma resposta à demanda por inovação das aulas de língua na escola.

O comportamento desprendido para a criação ou inovação, necessário à produção de jogos pedagógicos, tem sido modelado na experiência aqui compartilhada. Minha esperança é que, após conclusão da licenciatura, esse comportamento possa ser acionado pelas professoras como resposta aos distintos desafios que emergirão no local de trabalho, diante das constantes mudanças sociais. Os profissionais da educação precisam se sentir desafiados diante das transformações na sociedade.

No século XXI, não é possível insistir no transporte dos discentes escolares ou universitários - para outros planetas, durante o tempo de instrução formal e, consequentemente, o cumprimento do horário diário de instrução não pode significar o retorno à terra. Finalmente, retomo minha interlocução mais diretamente para dentro da universidade. $\mathrm{O}$ enfrentamento dos desafios da formação inicial de professoras por docentes é um compromisso ético. No contexto das licenciaturas, o enfrentamento serve de modelo para que as futuras professoras não reproduzam práticas semelhantes às quais foram amargamente experimentadas por elas, na própria trajetória escolar. Os desafios só se configuram como problemas quando são ignorados por agentes sociais diversos, resultando na reprodução da fragilidade na formação de professoras e, portanto, de alunos da escola básica.

\section{English Version}

In order to answer that question, I will assume as starting point a practical experience developed by me in the preservice education of Portuguese teachers for primary schools. My emphasis on higher education does not compromise the reader's understanding of the experience given the issues of pedagogical practices pertaining to different contexts, for instance, primary schools. When I direct energies to innovate in my pedagogical practices, I do not neglect Brazilian schools where most teachers work. The challenges prompt professionals to seek answers to improve their activities, albeit a few mistakenly take them as justification 
for irresponsible inertia. Using games as pedagogical resources or materials means actively dealing with challenges constitutive of teaching.

I have often faced the precarious linguistic education of first-year students of Pedagogy majors. These students' difficulties in reading, writing and linguistic analysis are recurrent. The challenge is aggravated by the risk of conserving these issues, which is posed by a suffocating curriculum that seems to ignore that the so-called polyvalent educators are also Portuguese teachers. Linguistic analysis has occupied a central position in my work as an educator because the reflection on how grammar works is necessary for a productive experience as college undergraduates and school teachers. Grammar knowledge can help reading and writing practices at university, which is evident, for example, when rewritings of academic genres are assigned. Why is that use of grammar inadequate? What are the possible reasons for a mistaken register? What are the grammar alternatives for a most suitable register? Questions such as these have to be asked and answered with a degree of autonomy by students. This same grammar knowledge added to the pedagogical knowledge is necessary at school to prevent the reproduction of a notorious tradition that has been shown to be little productive, particularly for children from unprivileged social classes.

I highlight the unproductive cycle because these practices are responsible for the numerous challenges brought on by Pedagogy first-year students. Some explicit grammar knowledge is necessary, from a functionalist perspective, and, due to the limited existence of vestiges of prescriptive grammar knowledge from school, new ones need to be constructed with these majoring teachers as response to emergent practical situations. The production of pedagogical games has become a promising path in this adverse context, which includes the limited hours per semester for the language teaching methodology course.

The games we make employ different resources, from stationary material, common in school settings, to recycled materials, such as milk cartons, plastic bottles and soda caps. By producing the games, pedagogy students come to grasp linguistic knowledge in a more sustainable way. It is impossible to adapt or even to create games to work possible linguistic constructions on the level of the word or the sentence, for example, without some explicit grammar knowledge. Learning to reflect metalinguistically on the grammar of Portuguese is usually hard for pedagogy undergraduate students - which does not hinder the ludic aspect of producing and playing the games during the course; on the contrary, the increasing linguistic awareness ensures some autonomy to work on and with the language, thus revealing the sustainability of the work developed and demanding constant improvement. In addition to reinforcing the linguistic literacy of future teachers, producing and making games part of the pedagogical planning has responded to the demand for innovation in language classes at school.

The behavior performed to create or to innovate, necessary to the production of pedagogical games, has been modeled by the experiences reported here. I have hopes that, after graduating, this behavior is activated by teachers in response to the various challenges that will rise in their workplace, as a result of the constant social changes. Education professionals need to feel challenged in the face of social transformation.

In the $21^{\text {th }}$ century, it is not possible to insist in transporting students school students or university ones - to a different planet during their instructional schedule nor can the end of their daily educational time mean a return to Earth. Finally, I resume my interlocution to address academia more directly. Facing 
the challenges of pre-service teacher education is, for university professors, an ethical commitment. In the context of teaching majors, such fight serves as a model for undergraduates not to reproduce practices similar to those they have bitterly experienced in their own school education. Challenges only become problems when they are ignored by different social agents, which leads to the reproduction of fragility in the education of teachers and, consequently, of primary school students.

\section{Com a palavra...}

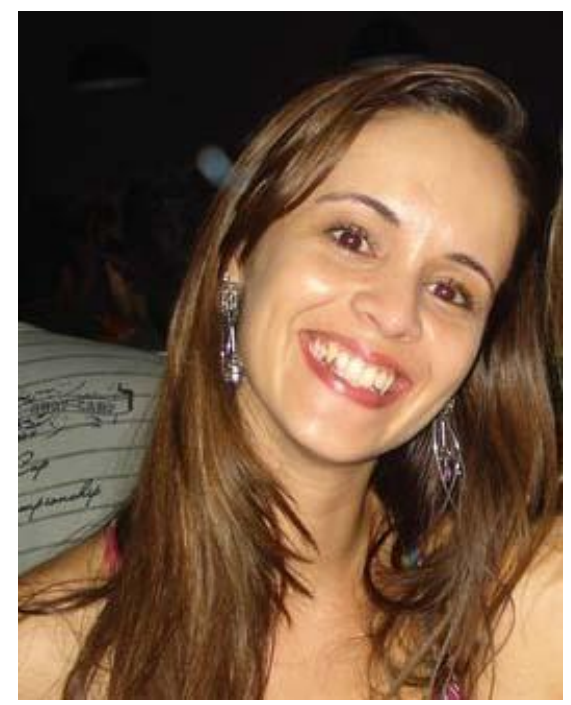

\section{Daniela Tavares Gontijo (UFPE)}

Em nossas vivências, construídas enquanto terapeutas ocupacionais atuantes em escolas públicas de Recife, utilizamos os jogos educativos como mediadores, com grande potencial para a construção de conhecimentos no campo da promoção de saúde. Entre os diferentes jogos que utilizamos na prática cotidiana, desenvolvemos o Kit BrincanTO.

O Kit BrincanTO é uma tecnologia social direcionada para a promoção de saúde sexual e reprodutiva de adolescente, construída a partir das experiências vivenciadas por docentes, pesquisadores e discentes vinculados ao Núcleo de Estudos e Pesquisas em Vulnerabilidade e Saúde na Infância e Adolescência da Universidade Federal de Pernambuco.A tecnologia é composta por um conjunto de 8 jogos educativos, sendo 3 na modalidade digital e 5 no formato físico. Os jogos abordam diferentes temáticas relacionadas a saúde sexual e reprodutiva na adolescência (mudanças corporais na adolescência, prevenção de infecções sexualmente transmissíveis, gravidez indesejada, prevenção de violência sexual, vivências da sexualidade de forma segura e gênero/sexualidade).

A construção da ação educativa é norteada pelos princípios da Pedagogia Paulo Freire, sendo destacada a importância da construção do diálogo para a sua efetivação. $\mathrm{O}$ diálogo na perspectiva freireana é fundamentado pela amorosidade (comprometimento com a causa da humanização), humildade (no reconhecimento e valorização de diferentes conhecimentos), fé no potencial dos seres humanos em transformarem a si e ao mundo, esperança enquanto atitude ativa de mobilizar mudanças e pensar crítico (aquele que se direciona não somente para a análise de uma situação cotidiana mas também para a sua transformação).

Estes princípios precisam se tornar materialidade nas ações educativas, através das atitudes do educador. Compreendemos que a escolha pelos jogos educativos, enquanto mediadores deste processo, traz inúmeras potencialidades para este processo. Inicialmente, a utilização dos jogos possibilita a criação de um ambiente de descontração para a abordagem de uma temática que ainda continua permeada por tabus e preconceitos. Assim, com a utilização dos jogos conseguimos criar um ambiente que facilita a vinculação do mediador com os adolescentes e uma maior motivação para a participação na ação, considerando a atratividade desta ferramenta nesta época da vida.

Além disso, os jogos foram elaborados de forma a permitir uma maior flexibilidade nas ações, quando comparadas com metodologias 
tradicionais (palestras), geralmente utilizadas no campo, e assim possibilitar que adolescentes e mediadores tragam para o cenário educativo os seus conhecimentos prévios. A partir destes conhecimentos, o mediador, em diálogo com os adolescentes, problematiza as questões trazidas pelos jogos de forma a possibilitar a reflexão crítica e a construção de saberes que possam contribuir para a adoção de atitudes saudáveis na vida. Em relação a este aspecto, consideramos que a proposta de alguns dos jogos, simulando situações da vida real, possibilita que os adolescentes possam exercitar, em ambiente seguro, os processos de tomada de decisão, contribuindo assim para a potencialização de sua autonomia.

Destacamos que, em nossas experiências, os jogos se constituem como mediadores da ação educativa, mas que estes só terão a sua efetividade plena se forem utilizados de acordo com a proposta pedagógica que nortearam a sua construção. Assim, o Kit BrincanTO foi desenvolvido para se constituir como uma experiência sempre mediada por um adulto, entendido aqui, conforme nos apresenta Paulo Freire, como mobilizador das condições de construção do conhecimento junto com os adolescentes.

Trazemos aqui a nossa defesa do potencial do diálogo da Pedagogia Paulo Freire com os jogos na construção de experiências educativas pautadas pela participação de todos os envolvidos, na condição de sujeitos do conhecimento. No sentido de contribuir com este "encontro", o NEPVIAS desenvolve processos formativos para a utilização do Kit Brincanto na íntegra, conforme descrito na plataforma de Tecnologias Sociais do Banco do Brasil (https://transforma.fbb.org.br/tecnologiasocial/kit-brincanto-jogos-e-promocao-desaude-sexual-e-reprodutiva-na-juventude).

Também disponibilizamos, de forma gratuita, por via eletrônica (nepviasufpe@gmail.com), os jogos digitais (e seus materiais de apoio) para que todos possam conhecer um pouco da nossa proposta e se aventurar conosco no desafio de construir ações educativas prazerosas, dialógicas e promotoras de humanização a todos os envolvidos.

\section{English Version}

In the course of our experiences as occupational therapists in public school in Recife, we have employed educational games as powerful mediators in the construction of knowledge in the field of health promotion. Among the games we use in our daily practices, we developed the Kit BrincanTO, which is a social technology directed at promoting sexual and reproductive health for teenagers.

The Kit BrincanTO was built from the experiences of teachers, researchers and undergraduate students from the Nucleus of Studies and Research on Vulnerability and Health in Childhood and Adolescence at Federal University of Pernambuco $^{14}$. The technology is composed of a set of 8 educational games, of which 3 are digital and 5 concrete games. The games approach different subjects related to sexual and reproductive health in adolescence (body changes in adolescence, prevention of sexually transmitted infections, unexpected pregnancy, prevention of sexual violence, safe sexuality and gender/sexuality).

The construction of this educational action was guided by Paulo Freire's Pedagogy, which highlights the importance of dialogue in its constitution. From a Freirean perspective, the dialogue is based on kindness (commitment to the cause of humanization), humility (recognition and valorization of different knowledge), faith in the potential of

${ }^{14}$ Núcleo de Estudos e Pesquisas em Vulnerabilidade e Saúde na Infância $e$ Adolescência (NEPVIAS)at Universidade Federal de Pernambuco 
human beings in transforming themselves and the world, hope as an active attitude of mobilizing change and critical thinking (that is directed not only to analysis of a daily situation but also its transformation).

These principles need to be materialized in educational actions through the educator's attitudes, and we understand that choosing educational games as mediators provides them with numerous potentialities. Initially, using games fosters a relaxed environment to approach a subject that still received with prejudice and taboos. Through the games, we were able to create an environment that facilitates bonds between the mediator and teenagers and motivates them to participate in the activity, given the attractiveness of the tools for this stage in life.

Furthermore, the games were built to allow more flexibility to the activities, compared to traditional methodologies (lectures) generally employed in this field, and to allow teenagers and mediators to bring their previous knowledge into the educational context. Based on this knowledge, the mediator dialogues with teenagers and discusses the questions posed by teenagers through the games. This triggers critical reflection and construction of knowledge that can lead to the adoption of healthy attitudes in life. In this regard, we argue that idea of games that simulate real life situationsallows teenagers to exercise, in a safe environment, decision making processes, which helps fostering their autonomy.

We highlight that, in our experiences, the games constitute mediators in the educational act, but they are only effective if used according to the pedagogical plan that grounded their creation. Therefore, Kit BrincanTO was developed to be an experience mediated by an adult, who is conceived here, as Paulo Freire proposed, as a mobilizer of conditions to construct knowledge with the teenagers.
Therefore, we defend here the potential of a dialogue between Paulo Freire's Pedagogy and games to build educational experiences grounded on the participation of all of the involved, in the condition of subjects of knowledge. In order to contribute with this dialogue, the Nucleus develops formative actions so the Kit BrincanTO can be used in its entirety, as described in the platform for Social Technologies of Banco do Brasil (https://transforma.fbb.org.br/tecnologiasocial/kit-brincanto-jogos-e-promocao-desaude-sexual-e-reprodutiva-na-juventude).

In addition, the digital games (and support materials) are made available electronically(nepviasufpe@gmail.com) for free, so everyone can know a little more about our proposal and join us in the challenge of creating educational actions that are pleasant, dialogical and humanizing for everyone involved.

\section{Com a palavra...}

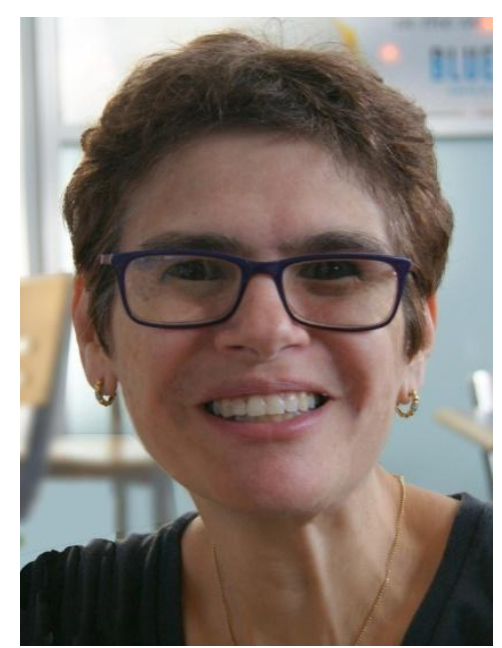

Renata Junqueira de Souza (UNESP/Presidente Prudente)

Como professora das metodologias e práticas com língua portuguesa (leitura, compreensão textual, produção e avaliação de textos) e coordenadora do CELLIJ - Centro de Estudos em Leitura e Literatura Infantil e Juvenil "Maria Betty Coelho Silva", sempre estimulei meus alunos do curso de Pedagogia a utilizarem jogos como ferramentas de ensino. 
No entanto, percebo que não é fácil, falta para o aluno: conhecer os jogos, mesmo aqueles mais usuais como forca e stop. Depois, outros mais comerciais: Imagem e ação, Pictureka, Scramble e até mesmo jogos que envolvam lugares, países e obras de arte.Ao apreciar tais jogos e praticá-los, o aluno compreenderá a dinâmica do ato de jogar, os seus objetivos, a possibilidade de socialização, de negociação e sociabilização com o outro.

$\mathrm{O}$ ensino da língua portuguesa não é fácil, envolve muitos conteúdos: desde a alfabetização até o preparo das crianças para compreender gêneros textuais diferentes e poder produzi-los.

No entanto, não basta ao futuro professor da educação infantil e dos anos iniciais jogar, compreender tal ferramenta como objeto de aprendizagem, pois além de um planejamento que preveja o jogo estar em suas aulas, o docente tem que compreender o que pretende com a construção de um jogo ou com a prática do mesmo em sala de aula.

Como professora, tenho ensinado construções de jogos que inicialmente desperte na criança a compreensão do conteúdo que está sendo trabalhado. Posso elencar algumas atividades feitas com os alunos da Pedagogia, nas quais solicitei que eles agissem como se fossem as crianças, que terão no futuro.

A bola do lide/lead: trata-se de uma bola de praia ou de parque de diversões com divisões coloridas, nas partes as questões: $\mathrm{O}$ que, quem, quando; onde, como; por que e para que. A atividade pode começar com a leitura de uma notícia de jornal e em círculo, joga-se a bola. No local onde a mão do aluno parar ele tem que resgatar a notícia lida e responder. A partir dessa primeira brincadeira - cujo objetivo é mostrar a estrutura do lide, outra pode ser proposta, dessa vez, a construção conjunta de uma notícia. Por exemplo, joga-se a bola e um aluno pega "onde", respondendo: em Camburi, litoral norte do Estado de São
Paulo. O mesmo estudante que criou o início da notícia joga a bola e suponhamos que o próximo discente pegue "o quê" e dê como resposta: o campeonato nacional de surf. E assim, o jogo prossegue até que a notícia seja concluída.

A mesma bola e o tipo de atividade podem ser utilizados para o trabalho com a estrutura do texto narrativo, a produção de um conto ou uma pequena história. Nessa opção, o professor deverá modificar as questões, lembrando-se a estrutura do texto narrativo: tempo, espaço, personagens, conflito, resolução do problema e desfecho.

Para a temática - produção do texto narrativo, gosto especialmente do baralho literário. Criado com um baralho normal, o professor deve nas partes dos naipes colar dois tipos de textos: o visual, escolhendo figuras inusitadas como princesas, detetives, duendes, mula-semcabeça, cemitério, cidades, castelos. A outra parte das cartas serão elaboradas com textos impressos e indicações: local onde se passará a história, esse/a será o protagonista do seu texto.

Em se tratando do baralho literário, os próprios alunos poderão praticar um outro tipo de gênero antes de jogar com as cartas. Trata-se do texto instrucional, as crianças poderão aprender com $\mathrm{o}$ professor, o que é um texto instrucional, conhecer modelos, desde bulas, receitas até folhetos de aparelhos domésticos e jogos comercializados. A partir do contato com esses modelos, o aluno compreenderá a linguagem utilizada, os substantivos concretos acompanhados de numerais e as funções dos verbos no imperativo, subjuntivo e/ou indicativo, bem como entenderá que as instruções usualmente configuram-se com orações bimembres, com verbos no imperativo (jogar o dado para verificar que participante iniciará o jogo) ou orações unimembres formadas com o verbo no infinitivo (distribuir seis cartas para cada participante). Acredita-se que, dessa maneira, o aprendizado terá mais significado e o aluno compreenderá 
melhor o gênero, o tipo textual, as funções do texto instrucional.

Assim, a partir da confecção do baralho literário e das regras específicas, criada em sala de aula, com ajuda do docente, os alunos poderão experienciar outro jogo como uma tentativa de elaboração de um conto ou texto narrativo, individualmente.

Poderia ainda relatar atividades feitas com jogos de vocabulário, construção de glossários, compreensão e produção do texto descritivo, e até um jogo de tabuleiro, em que o professor avalia a aprendizagem do aluno. Nesse caso, jogar significa sintetizar o aprendizado e o docente poderá então ponderar quais conteúdos deverá trabalhar novamente. No entanto, nessa pequena entrevista não teremos espaço para isso.

Para finalizar, posso dizer que o jogo é um excelente incentivo para construção de conhecimentos da língua portuguesa e, principalmente, oferece a nós professores, uma fonte inesgotável de ideias para motivar nossos alunos a aprender. É preciso ressaltar a utilização dos jogos. E que essa utilização e ensino possam estimular os alunos a conhecer, brincar e aprender.

\section{English Version}

As a professor of Portuguese teaching methods and practices (reading, writing and assessing texts) and coordinator of the Center of Studies in Reading and Literature for Children and Teenagers "Maria Betty Coelho Silva"15, I have always stimulated Pedagogy undergraduate students to use games as teaching tools.

However, I realize this is not easy since students lack knowledge of games, even the most common as hangman and stop; to the most commercial games:

\footnotetext{
${ }^{15}$ In Portuguese: Centro de Estudos em Leitura e Literatura Infantil e Juvenil "Maria Betty Coelho Silva"
}

Pictionary, Pictureka, Scramble; and even games that involve places, countries and works of art. By enjoying and playing games, students understand the dynamics of the act of playing, its goals, and the possibility of socialization and negotiation.

The teaching of Portuguese is not easy, it involves many aspects: from alphabetizing to understanding different text genres and being able to produce them.

Nonetheless, it is not enough for kindergarten and primary school preservice teachers to understand such tools as objects of learning because, in addition to planning lessons with games, they have to understand the aim of making or playing a game during classes

As a teacher, I have taught the construction of games that primarily wake in children the understanding of the subject in question. I can list some activities I developed with Pedagogy undergraduates in which I asked them to act as kids, such as the ones they will teach in the future.

The lead ball: a beach ball or one of those you take to the park divided into colored stripes with the questions: what, who, when, where, how, why, what for. The game can start with the reading of a newspaper with students arranged in a circle to pass the ball. The word on which a student's hand lands indicates the question for which he needs to recover the information in the lead. After the first game - that aims to show the structure of the lead - another one can be proposed, this time, the collective writing of a news story. For example, the ball is passed and one student catches the word "where" to answer: in Camburi, north coast of São Paulo. The same student who created the beginning of the news passes the ball and, let's imagine, the next one catches "what" and answers: the surf national championship. And the game progresses until the whole story is finished. 
This same ball and activity can be used to work the structure of the narrative text, to write a short story or a tale. Then, the teacher needs to change the questions to attend to the structure of the narrative next: time, space, characters, conflict, solution and end.

Regarding the theme - narrative productions - I like the literary card game in particular. The teacher uses cards shaped like the normal cards but replaces the suits with two types of texts: the first one is visual, with curious figures of princesses, detectives, dwarves, headless beast, cemeteries, cities, castles. The second is made with print texts and suggestions: places where the story is set, the protagonist.

In regard to the literary work, students can practice with a different genre before playing cards. I refer to the instructional text in which children can learn with the teacher what an instructional text is, and explore their models, from medicine instruction to recipes and instructions for appliances and marketed games. Based on these models, students can understand the language concrete nouns followed by numbers and the functions of imperative, subjunctive and/or indicative. They also understand instructions are usually set as two-part sentences with imperative verbs (a dice is played to decide who starts the game) or one-part sentences formed with infinitive verbs (six cards each player). This way, learning is meaningful and the student can better understand the genre, the text type, the functions of the instructional text.

Therefore, confection of literary cards and specific in-class rules as well as teacher's assistance allow students to experience a different game to try to elaborate a short story or a narrative text, individually.

I could also report activities that rely on vocabulary games, building of glossaries, understanding and making a descriptive text and even a board game in which the teacher assesses learning.
Playing games, then, mean synthesizing learning, and the teacher can ponder which subjects should be worked on again. However, this short interview makes no room for that.

Finally, I can say games are excellent incentives to construct knowledge on Portuguese language and, mostly, they offer us, teachers, an endless source of ideas to motivate our students to learn. Playing games must be highlighted. Games and teaching can prompt students to explore, to play and to learn.

\section{Com a palavra...}

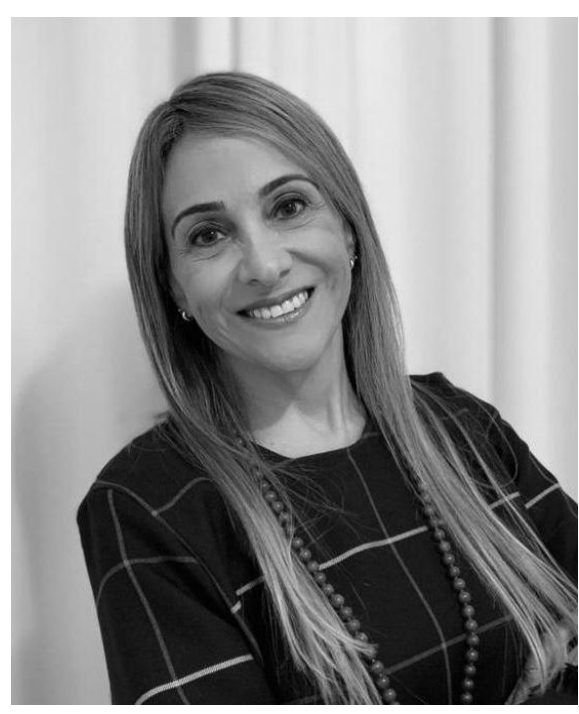

\section{FabianeVerardi Burlamaque (UPF)}

As mudanças provocadas pelas tecnologias digitais influenciaram sobremaneira a cultura e a sociedade, elas introduziram a ubiquidade $^{16}$ entre os atributos das relações humanas. Isso significa que os dispositivos tecnológicos conectados em rede estão disponíveis em todos os lugares, em diversos tamanhos e, cada vez mais, incorporados em objetos e ferramentas de uso cotidiano. Assim, é necessário que a escola, nesta sociedade conectada, ou melhor, hiperconectada, assuma a função de "orientar os percursos

${ }^{16}$ Santaella, L. (2013). Comunicação ubíqua. $1^{\text {a }}$ ed. São Paulo: Paulus, 2013. 
individuais no saber e de contribuir para o reconhecimento dos conjuntos de saberes pertencentes às pessoas". ${ }^{17}$ Dessa forma, mais do que nunca, é preciso pensar em metodologias e recursos que tornem as aulas mais dinâmicas e de acordo com este aluno que é nativo da era digital. Nessa nova diretriz, jogos, desafios,tanto quanto a gamificação nos processos de aprendizagem são alternativas metodológicas que auxiliam na motivação e no envolvimento do aluno nas atividades.

Quando se fala em gamificar a aprendizagem, o objetivo é produzir algo que seja envolvente e interessante, que transporte os alunos para um "círculo mágico" no qual os problemas e preocupações cotidianas são suspensas, podendo, assim, ser substituídas pelo jogo ${ }^{18}$ que lhes possibilita, por meio do engajamento e do compartilhamento de conhecimentos.

A minha experiência com a utilização da gamificação como alternativa metodológica na formação de leitores foi utilizada, em 2017, na $16^{\mathrm{a}}$ Jornada Nacional de Literatura e $8^{\mathrm{a}}$ Jornadinha Nacional de Literatura, da Universidade de Passo Fundo, na cidade de Passo Fundo, Rio Grande do Sul, Brasil. Tal atividade foi proposta por meio de um aplicativo denominado JornadApp, que tinha duas funcionalidades: "JornadApp na escola" e "Projetos transversais: rotas leitoras". O software foi desenvolvido com patrocínio da BSBIOS e o conteúdo foi elaborado pela comissão organizadora das Jornadas Literárias da Universidade de Passo Fundo, Rio Grande do Sul, Brasil.

$\mathrm{O}$ aplicativo integrou várias funcionalidades de interação em um celular como leitura de Qrcode e posicionamento georreferenciado, por meio de mapas. $\mathrm{O}$ usuário precisava ter o

\footnotetext{
${ }^{17}$ Lévy, P. (1999). Cibercultura. São Paulo: Editora 34, 1999.

${ }^{18}$ Huizinga, J. (2000). Homo Ludens: o Jogo Como Elemento da Cultura. $4^{\mathrm{a}}$ ed. São Paulo: Perspectiva, 2000.
}

conhecimento prévio das obras para poder interagir e responder às atividades, integrando o conhecimento literário e os recursos da tecnologia. $\mathrm{O}$ programa consistiu em um jogo em sistema Android ou IOS, disponibilizando, gratuitamente, download e upload de dados. Destacaseque foram realizados 1.236 (mil duzentos e trinta e seis) downloads durante os meses que antecederam o evento. É importante destacar que 55(cinquenta e cinco) escolas de Passo Fundo e região aderiram ao JornadApp para as atividades da Pré-Jornadinha, leitura prévia das obras dos autores que estariam presentes àquela edição da Jornadinha. Um dado importante éque, dessas escolas, $93 \%$ pertenciam à rede educacional pública.

Em relação ao funcionamento do aplicativo, o mediador fazia o download do aplicativo em seu celular, cadastrava a turma, ou a escola, e registrava as tarefas cumpridas. A tela inicial do aplicativo possuía duas funções: JornadApp na Escola e Projetos Transversais. O professor clicava na primeira opção, cadastrava-se como novo participante, caso fosse o primeiro contato com $\mathrm{o}$ aplicativo; ou fazia seu login normalmente ou clicava em visitante, caso não pertencesse a cidade de Passo Fundo. Após, podia escolher com qual ano do Ensino Fundamental iria trabalhar e uma lista de obras e atividades estava à disposição.

O aplicativo apresenta 21 obras dos escritores participantes da Jornadinha e com 22 atividades gamificadas, que foram divididas por série/ano Do primeiro ao quinto ano do Ensino Fundamental I, o aplicativo disponibilizou 10 atividades pertencentes às obras $O$ livro que lê gente, de Alexandre Gomes; Monstros do cinema, de Daniel Kondo e Augusto Massi; Poeminhas da terra, de Márcia Leite; O livro do palavrão, de Selma Maria; Adélia, de Jean Claude Alphen; Roupa de brincar, de Eliandro Rocha; Tony Moon, de Pedro Duarte; Oriê, de 
Lúcia Hiratsuka; Como nasceram as estrelas, de Clarice Lispector.

Do sexto ao nono ano do Ensino Fundamental II, 12 atividades gamificadas foram disponibilizadas: A arma escarlate, de Renata Ventura; Flor de Guernica, de Pablo Morenno; Uma escuridão bonita, de Ondjaki; Quem matou o livro policial, de Luiz Antônio de Aguiar; Ouro, fogo e megabytes, de Felipe Castilho; Auto da Compadecida, de Ariano Suassuna; Iluminuras, de Rosana Rios; Quando o Sol encontra a Lua, de Renata Tufano; A fonte do esquecimento, de HeloisaPrieto; $O$ homem que fazia chover, de Carlos Drummond de Andrade; $O$ navio das cores, de MoacyrScliar.

As atividades gamificadas propostas proporcionaram a interação entre autores, obras e leitores, a fim de despertar a criatividade dos alunos por meio da produção e da socialização dessas vivências. $\mathrm{O}$ aplicativo possibilitou diferentes desafios gamificados em que professores e alunos trabalharam juntos, trocando experiências sobre os autores, as obras, não levando apenas ao efeito estético que ela proporciona, mas também, às reflexões sobre a humanidade e as diferenças.

A partir desta experiência, verificou-se as potencialidades da gamificação quando aplicada em processos de ensino e aprendizagem com o objetivo de formar leitores e despertar a imaginação por meio das atividades propostas. A gamificação é uma estratégia pedagógica que pode, certamente, auxiliar na motivação e no engajamento do estudante, uma vez que ela se apresenta um método eficiente de tornar a leitura e o trabalho com a literatura uma experiência prazerosa, capaz de engendrar o futuro leitor.

\section{English Version}

Changes caused by digital technologies influenced culture and society intensely, they introduced ubiquity ${ }^{19}$ into attributes of human relations. This means that technological devices with network connection are available everywhere, in different sizes and, ever more so, incorporated in objects and tools of our daily use. Therefore, is it necessary for schools, in this connected, better yet, hyperconnected society, to assume the role of "guiding individual trajectories in knowing and of contributing with the recognition of the set of knowledge that belongs to people". ${ }^{20}$ More than ever, it is necessary to conceive methods and resources that make classes more dynamic and in agreement with this digital native student. Therefore, games, challenges and gamification in learning are methodologic alternatives that foster students' motivation and involvement in different activities.

Learning gamification aims at producing something that is attractive and interesting, something that takes students to a "magical circle" in which daily problems and concerns are put in suspension and replaced with the game ${ }^{21}$, which allows them, through engagement, to share knowledge.

My experience with gamification as methodologic alternative in the education of readers was used, in 2017, during the $16^{\text {th }}$ National Literary Journey (16 Jornada Nacional de Literatura) and in the $8^{\text {th }}$ Literary Short Journey (Jornadinha Nacional de Literatura), at University of Passo Fundo (Universidade de Passo Fundo), in Passo Fundo, Rio Grande do Sul, Brazil. This activity was proposed through an app called JornadApp, which had two functions: "JornadApp at school" and "Transversal Projects: reading routes". The software development was sponsored by BSBios and the content was elaborated

${ }^{19}$ Santaella, L. (2013). Comunicação ubíqua. $1^{\mathrm{a}}$ ed. São Paulo: Paulus, 2013.

${ }^{20}$ Lévy, P. (1999). Cibercultura. São Paulo: Editora 34, 1999.

${ }^{21}$ Huizinga, J. (2000). Homo Ludens: o Jogo Como Elemento da Cultura. $4^{\mathrm{a}}$ ed. São Paulo: Perspectiva, 2000. 
by the organizing committee of both Literary Journeys in Passo Fundo, Rio Grande do Sul, Brazil. The app integrated several interactional functions of a cellphone, such as $\mathrm{QR}$ code reading and georeferenced position through maps. Users need to know beforehand the literary works to interact and answer the activities, thus integrating literary knowledge and technological resources. The program was an Android/IOS game with free download and upload. It is noted the figure of 1.236 (a thousand two hundred and thirty-six) downloads in the months preceding the vent. Also, 55 (fifty-five) schools in Passo Fundo joined JornadApp in the PreJourney activities and previous reading of the works of guest authors in that edition of the Short Journey. An significant data that $93 \%$ of the schools belonged to the public sector.

Regarding the app, it required the school mediator to download the application on their cellphone, register the class or school and report the completion of each task. The initial screen displayed two functions: JornadApp at School and Transversal Projects. Teachers would select the first option, register as new participants in the case of a first contact with the app; do the usual log in or click "guest access", in the case of someone from outside Passo Fundo. Then, they could choose which Primary School they would work with; a list of works and activities would become available then.

The application presented all 21 works of guest authors at the Short Journey and 22 gamified activities divided by year/grade. First to fifth grades in Primary School would find 10 activities available on the app for the following works: O livro que lê gente, by Alexandre Gomes; Monstros do cinema, by Daniel Kondo and Augusto Massi; Poeminhas da terra, by Márcia Leite; $O$ livro do palavrão, by Selma Maria; Adélia, by Jean Claude Alphen; Roupa de brincar, by Eliandro Rocha; Tony Moon, by Pedro
Duarte; Oriê, by Lúcia Hiratsuka; Como nasceram as estrelas, by Clarice Lispector.

Sixth to nineth grades in Secondary School would find 12 gamified activities available on the app for these works: $A$ arma escarlate, by Renata Ventura; Flor de Guernica, by Pablo Morenno; Uma escuridão bonita, by Ondjaki; Quem matou o livro policial, by Luiz Antônio de Aguiar; Ouro, fogo e megabytes, by Felipe Castilho; Auto da Compadecida, by Ariano Suassuna; Iluminuras, by Rosana Rios; Quando o Sol encontra a Lua, by Renata Tufano; A fonte do esquecimento, by HeloisaPrieto; $O$ homem que fazia chover, by Carlos Drummond de Andrade; $O$ navio das cores, by MoacyrScliar.

The app gamified activities enabled interaction between authors, works and readers to awaken creativity in students through producing and sharing of experiences. The application had different gamified challenges in which teachers and students worked together, exchanging experiences about the authors and their works, taking into account not only the aesthetic factor, but reflections on humanity and differences.

These experiences enabled us to verify the potentialities of gamifications applied to teaching and learning in order to educate readers and stimulate imagination through the activities on the app. Gamification is a pedagogical strategy that certainly helps motivating and engaging students because it represents an effective method to make reading and working with literature a pleasant experience that sponsors future readers. 


\section{Com a palavra...}

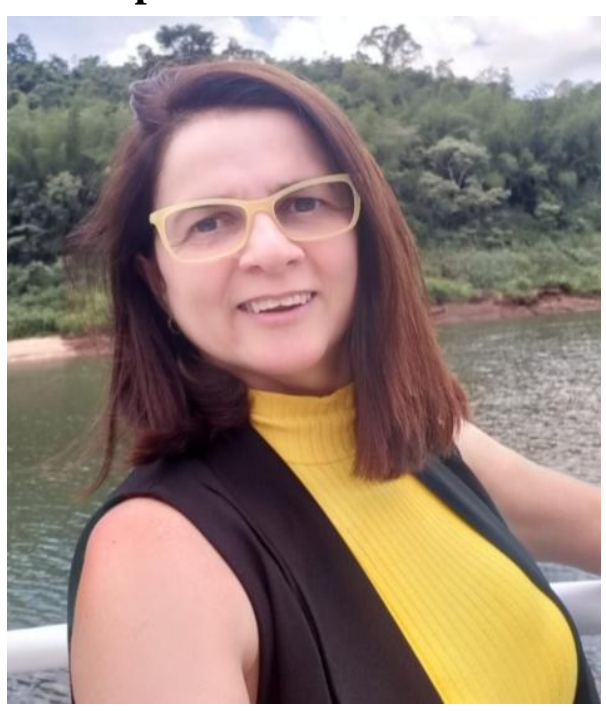

Regina Cláudia Pinheiro (UECE)

Os jogos são objetos culturais utilizados como prática social há muitos anos. Além do passatempo que lhes é inerente, eles proporcionam aprendizagens diversas sobre comportamentos (físicos, cognitivos, sociais, dentre outros), conteúdos (nas mais variadas disciplinas) e uso de ferramentas (analógicas e digitais). Por esta razão, os jogos já vêm sendo utilizados nas salas de aula há muito tempo, com a finalidade de tornar a aprendizagem mais lúdica, possibilitando, dessa forma, maior motivação para a prática de determinadas atividades pelos alunos.

Atualmente, percebem-se diversas transformações nas práticas sociais dos indivíduos, ocasionadas, principalmente, pela inserção das tecnologias digitais de informação e comunicação (TDIC), que mudaram as maneiras de se informar e se comunicar. Essa mudança de comportamento também é identificada nas formas de se divertir, pois é muito comum observar pessoas se entretendo através da interação com o uso das tecnologias digitais. Com relação a essas práticas de entretenimento com o uso das TDICs, verifica-se que os jogos digitais têm sido apreciados por pessoas de todas as faixas etárias. No entanto, crianças e jovens são o público que mais interage com esses recursos.

Em uma pesquisa que realizei com crianças do $5^{\circ}$ ano do Ensino Fundamental de escolas públicas do município de Tauá$\mathrm{CE}$, verifiquei que a maior parte delas utilizavam as ferramentas digitais para jogar e que as atividades preferidas, quando frequentavam o laboratório de informática das escolas, estavam relacionadas a jogos (PINHEIRO, 2018) ${ }^{22}$. Essas contestações me impulsionaram a elaborar um projeto de extensão que criasse jogos e atividades digitais para serem disponibilizados em escolas públicas, pois os docentes dessas instituições declaravam que a maioria dos jogos da internet não permitiam seu uso off line e as escolas não possuíam uma rede muito estável.

Por acreditar nas potencialidades pedagógicas dos jogos e ouvir os relatos citados anteriormente, criei o Banco de Letramento Digital para Língua Portuguesa que conta com jogos e atividades digitais que possibilitam aos alunos os processos de alfabetização e letramentos. Este banco criado, principalmente, para discentes das séries iniciais do Ensino Fundamental, possui jogos digitais que são adaptações de jogos físicos, com alguns aspectos que tornam as ações contextualizadas, e outros jogos contam com elementos característicos do mundo dos games, objetos culturais muito utilizados por crianças e jovens.

Os games possuem elementos que atraem muito os indivíduos, tais como objetivos, regras, competição, recompensas, feedback, níveis dentre outros que geram engajamento nos usuários (KAPP, 2012) 23 $^{23}$ O mundo dos

22 PINHEIRO, Regina Cláudia. Conceitos e modelos de letramento digital: o que escolas de ensino fundamental adotam? Linguagem em (Dis)curso, Tubarão/SC, v. 18, n. 3, p. 603-622, set./dez. 2018.

${ }^{23}$ KAPP, Karl. The gamification of learning and instruction: game-based methods and strategies 
games e seus elementos invadiram a vida de muitas crianças e jovens e a utilização desses elementos em situações que não se trata de jogos digitais já está sendo inserida em empresas, instituições escolares e em diversos cursos para engajar os participantes. Para a utilização desses elementos em práticas que não estão relacionadas aos games, Nick Pelling criou, em 2003, o termo gamificação (ALVES, 2015) ${ }^{24}$. Dessa forma, segundo Kapp (2012), a gamificação é o uso dos elementos dos games para motivar as pessoas, com o intuito de resolver problemas e promover a aprendizagem.

Nas instituições educacionais, os processos de gamificação já estão sendo utilizados e podem ser úteis para engajar os alunos. No entanto, é importante ressaltar que, apesar de as práticas de gamificação terem surgido a partir de games digitais, sua utilização em outras situações não requer, necessariamente, o uso de tecnologias. Sendo assim, os elementos dos jogos digitais, que já são conhecidos por crianças e adolescentes, podem ser utilizados para engajar os alunos nas resoluções de seus problemas e para aprendizagem de diversos conteúdos, a fim de que estes se sintam mais motivados para interagir com os conteúdos curriculares.

\section{English Version}

Games are cultural objects used as social practices for many years. In addition to the inherent past time, they enable several learnings on behavior (physical, cognitive, social and others) and on the use of tools (analogical or digital). For these reasons, games have

for training and education. San Francisco: Pfeiffer, 2012.

24 ALVES, Flora. Gamification: como criar experiências de aprendizagem engajadoras/ um guia completo do conceito à prática. São Paulo: DVS Editora, 2015. been used in classrooms to make learning playful and to enhance learners' motivation toward certain activities.

Nowadays, several transformations in social practices prompted mainly by the insertion of digital technologies of information and communication (DTIC) that changed the ways of informing and communicating. This change in behavior is also identified in the ways we have fun, as it became more frequent for people to get entertainment from digital technologies. Regarding the DTICs entertainment practices, it is verified that digital games are appreciated by people of all ages. However, children and teenagers Interact with these resources the most.

One research I conducted with children in the $5^{\text {th }}$ grade in Primary Schools in the city of Tauá, Estate of Ceará, Brazil, I verified that most students used digital tools to play and their preferred activities in the school computer lab were game-related (PINHEIRO, 2018). ${ }^{25}$ These data prompted me to write an extension project to create games and digital activities that would be available for public schools because teachers in these institutions often argued that internet games did not allow offline use and schools lacked stable internet.

By believing in the pedagogical potentialities of games and hearing those reports, I designed the Digital Literacy Bank for Portuguese Language, which gathers games and digital activities that allow students processes of alphabetization and literacies. The Bank was designed, mainly, for primary school students, with digital games that adapt actual physical games by adjusting aspects that contextualize actions, and games that use elements typically from the world of games, cultural objects widely used by children and teenagers.

25 PINHEIRO, Regina Cláudia. Conceitos e modelos de letramento digital: o que escolas de ensino fundamental adotam? Linguagem em (Dis)curso, Tubarão/SC, v. 18, n. 3, p. 603-622, set./dez. 2018. 
Games have very attractive elements for people, such as goals, rules, competition, rewards, feedback and levels, among many other ways of engaging users (KAPP, 2012). ${ }^{26}$ The world of games and their elements have invaded the lives of children and teenagers and using those elements in contexts outside the digital games is something that companies and educational institutions are doing to engage participants. In order to use game elements in game unrelated practices, Nick Pelling coined, in 2003, the word gamification (ALVES, 2015). ${ }^{27}$ Kapp (2012), then, defines gamification as the use of game elements to motivate people, to solve problems and to promote learning.

In educational institutions, gamification processes are already in use and can be effective ways of engaging students. It is noteworthy that, in spite of the rise of gamification processes after the event of digital gaming, the application in different contexts does not necessarily mean using technology. Therefore, digital games that are familiar to children and teenagers can be used to engage students in solving problems and learning different subjects, as they are more motivated to interact with the different school subjects.

\footnotetext{
${ }^{26} \mathrm{KAPP}$, Karl. The gamification of learning and instruction: game-based methods and strategies for training and education. San Francisco: Pfeiffer, 2012.

${ }^{27}$ ALVES, Flora. Gamification: como criar experiências de aprendizagem engajadoras/ um guia completo do conceito à prática. São Paulo: DVS Editora, 2015.
} 
RESPOSTA

Caça-palavras

Quem são os Entrevistados?

\begin{tabular}{|c|c|c|c|c|c|c|c|c|c|c|c|c|c|c|c|c|}
\hline $\mathbf{E}$ & $\mathbf{X}$ & $\mathbf{N}$ & $\mathbf{G}$ & 0 & $\mathbf{N}$ & $\mathbf{T}$ & I & $\bar{J}$ & 0 & $\mathbf{L}$ & $\mathbf{P}$ & $\mathbf{P}$ & $\mathbf{F}$ & B & $\mathbf{A}$ & $\mathbf{E}$ \\
\hline $\mathbf{T}$ & $\mathbf{W}$ & $\mathbf{J}$ & $\mathbf{E}$ & $\mathbf{R}$ & $\mathbf{Q}$ & O & $\mathbf{F}$ & 0 & $\mathbf{N}$ & $\mathbf{T}$ & $\mathbf{L}$ & $\mathbf{M}$ & $\mathbf{U}$ & $\mathbf{U}$ & $\mathbf{S}$ & $\mathbf{N}$ \\
\hline $\mathbf{A}$ & $\mathbf{V}$ & $\mathbf{U}$ & B & $\mathbf{I}$ & $\mathbf{W}$ & $\mathbf{Y}$ & $\overline{\mathbf{U}}$ & G & $\mathbf{D}$ & $\mathbf{A}$ & $\mathbf{G}$ & $\mathbf{A}$ & $\mathbf{F}$ & $\overline{\mathbf{R}}$ & $\mathbf{N}$ & $\overline{\mathbf{A}}$ \\
\hline $\bar{D}$ & $\mathbf{A}$ & $\mathbf{N}$ & I & $\mathbf{E}$ & $\mathbf{L}$ & $\overline{\mathbf{A}}$ & $\mathbf{F}$ & 0 & $\mathbf{E}$ & $\mathbf{V}$ & $\mathbf{E}$ & $\mathbf{R}$ & $\overline{\mathbf{A}}$ & $\mathbf{L}$ & D & $\mathbf{I}$ \\
\hline $\mathbf{I}$ & $\mathbf{F}$ & $\mathbf{Q}$ & $\mathbf{K}$ & $\mathbf{H}$ & $\mathbf{O}$ & D & $\mathbf{A}$ & $\mathbf{S}$ & $\mathbf{R}$ & $\mathbf{A}$ & $\mathbf{C}$ & I & I & $\mathbf{A}$ & D & B \\
\hline $\mathbf{O}$ & $\mathbf{U}$ & $\mathbf{U}$ & $\mathbf{J}$ & $\mathbf{N}$ & $\mathbf{M}$ & $\mathrm{C}$ & I & , & I & $\mathbf{R}$ & $\mathbf{T}$ & $\mathbf{A}$ & $\mathbf{J}$ & $\mathbf{M}$ & $\mathbf{L}$ & $\mathbf{A}$ \\
\hline $\mathbf{N}$ & $\mathbf{F}$ & $\mathbf{E}$ & $\mathbf{T}$ & I & $\mathbf{C}$ & H & $\mathbf{E}$ & L & D & $\mathbf{E}$ & $\mathbf{R}$ & $\mathbf{X}$ & $\mathbf{J}$ & $\mathbf{A}$ & $\mathbf{E}$ & $\mathbf{F}$ \\
\hline I & $\mathbf{A}$ & I & B & $\mathbf{P}$ & $\mathbf{U}$ & $\mathbf{U}$ & $\mathbf{J}$ & $\mathbf{E}$ & $\mathbf{S}$ & $\mathbf{S}$ & $\mathbf{U}$ & $\mathbf{U}$ & $\mathbf{J}$ & $\mathbf{Q}$ & I & $\mathbf{F}$ \\
\hline $\mathbf{S}$ & I & $\mathbf{R}$ & W & $\mathbf{E}$ & $\mathbf{Y}$ & $\mathbf{J}$ & B & $\mathrm{T}$ & $\mathbf{E}$ & $\mathbf{F}$ & $\mathbf{J}$ & $\mathbf{V}$ & $\mathbf{R}$ & $\mathbf{U}$ & $\mathbf{Z}$ & I \\
\hline I & $\mathbf{J}$ & A & $\mathbf{Z}$ & $\mathbf{X}$ & $\mathbf{L}$ & $\mathbf{O}$ & $\mathbf{U}$ & $\mathbf{R}$ & D & $\mathbf{E}$ & $\mathbf{S}$ & D & $\mathbf{G}$ & $\mathbf{E}$ & $\mathbf{O}$ & I \\
\hline 0 & $\mathbf{F}$ & $\mathbf{O}$ & $\mathbf{A}$ & $\mathbf{F}$ & $\mathbf{R}$ & $\mathbf{S}$ & $\mathbf{H}$ & $\mathbf{A}$ & B & D & I & $\mathbf{Y}$ & $\mathbf{L}$ & $\mathbf{S}$ & $\mathbf{H}$ & $\mathbf{S}$ \\
\hline $\mathbf{R}$ & $\mathbf{U}$ & $\mathbf{A}$ & $\mathbf{F}$ & $\mathbf{R}$ & $\mathbf{N}$ & $\mathbf{E}$ & $\mathbf{H}$ & $\mathbf{M}$ & $\mathbf{P}$ & C & $\mathbf{L}$ & A & $\mathbf{U}$ & D & I & $\mathbf{A}$ \\
\hline I & $\mathbf{F}$ & $\mathbf{I}$ & I & $\mathbf{A}$ & D & B & I & $\mathbf{E}$ & I & $\mathbf{K}$ & $\mathbf{V}$ & $\mathbf{C}$ & $\mathbf{C}$ & $\mathbf{S}$ & $\mathbf{Z}$ & $\mathbf{T}$ \\
\hline $\mathbf{N}$ & $\mathbf{A}$ & $\mathbf{V}$ & B & $\mathbf{R}$ & $\mathbf{E}$ & $G$ & I & $\mathbf{N}$ & $\mathbf{A}$ & $\mathbf{R}$ & $\mathbf{A}$ & $\mathbf{H}$ & I & $\mathbf{E}$ & $\mathbf{T}$ & $\mathbf{A}$ \\
\hline $\mathbf{R}$ & $\mathbf{A}$ & $\mathbf{F}$ & $\mathbf{R}$ & $\mathbf{N}$ & $\mathbf{R}$ & $\mathbf{R}$ & $\mathbf{A}$ & $\mathrm{T}$ & $\mathbf{U}$ & $\mathbf{U}$ & $\mathbf{J}$ & $\mathbf{N}$ & $\mathbf{A}$ & B & $\mathbf{R}$ & $\mathbf{N}$ \\
\hline $\mathbf{H}$ & $\mathbf{S}$ & $\mathbf{E}$ & $\mathbf{U}$ & G & I & $\mathbf{R}$ & D & 0 & $\mathbf{R}$ & $\mathbf{E}$ & $\mathbf{V}$ & $\mathbf{G}$ & $\mathbf{U}$ & $\mathbf{N}$ & B & $\mathbf{E}$ \\
\hline $\mathbf{J}$ & $\mathbf{O}$ & $\mathbf{A}$ & $\mathbf{F}$ & $\mathbf{R}$ & $\mathbf{N}$ & $\mathbf{A}$ & $\mathbf{P}$ & $\mathbf{S}$ & $\mathbf{U}$ & $\mathbf{M}$ & $\mathbf{R}$ & $\mathbf{A}$ & $\mathbf{F}$ & $\mathbf{R}$ & $\mathbf{N}$ & $\mathbf{R}$ \\
\hline $\mathbf{L}$ & $\mathbf{A}$ & $\mathbf{K}$ & $\mathbf{A}$ & $\mathbf{L}$ & 0 & $\mathbf{S}$ & I & 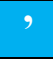 & $\mathbf{L}$ & $\mathbf{L}$ & $\mathbf{E}$ & D & $\mathbf{S}$ & $\mathbf{K}$ & $\mathbf{S}$ & $\mathbf{U}$ \\
\hline $\mathbf{U}$ & $\mathbf{R}$ & $\mathbf{A}$ & $\mathbf{G}$ & $\mathbf{V}$ & B & $\mathbf{E}$ & $\mathbf{T}$ & $\mathbf{E}$ & $\mathbf{N}$ & $\mathbf{E}$ & $\mathbf{N}$ & $\mathbf{R}$ & $\mathbf{A}$ & $\mathbf{F}$ & $\mathbf{R}$ & $\mathbf{N}$ \\
\hline $\mathbf{A}$ & $\mathbf{E}$ & $\mathbf{Q}$ & $\mathbf{E}$ & $\mathbf{P}$ & $\mathbf{E}$ & $\mathbf{R}$ & $\mathbf{E}$ & $\mathrm{T}$ & D & B & $\mathbf{G}$ & $\mathbf{X}$ & $\mathbf{F}$ & $\mathbf{G}$ & $\mathbf{N}$ & $\mathbf{E}$ \\
\hline $\mathbf{E}$ & $\mathbf{S}$ & D & $\mathbf{V}$ & $\mathbf{S}$ & D & G & $\mathbf{E}$ & I & $\mathbf{E}$ & $\mathbf{M}$ & $\mathbf{A}$ & G & $\mathbf{D}$ & $\mathbf{A}$ & $\mathbf{M}$ & $\mathbf{V}$ \\
\hline $\mathbf{O}$ & $\mathbf{A}$ & $\mathbf{F}$ & $\mathbf{R}$ & $\mathbf{I}$ & I & $\mathbf{A}$ & D & C & $\mathbf{R}$ & $\mathbf{H}$ & $\mathbf{W}$ & $\mathbf{L}$ & $\mathbf{A}$ & $\mathbf{K}$ & $\mathbf{A}$ & $\mathbf{L}$ \\
\hline $\mathbf{Z}$ & I & $\mathbf{L}$ & D & $\mathbf{S}$ & 0 & $\mathbf{U}$ & $\mathbf{Z}$ & $\mathbf{A}$ & I & O & $\mathbf{S}$ & D & $\mathbf{V}$ & $\mathbf{S}$ & D & $\mathbf{G}$ \\
\hline
\end{tabular}

